\title{
Corporate Governance, Growth Opportunities dan Konservatisme Akuntansi: Bukti Empirik pada Perusahaan Manufaktur di Bursa Efek Indonesia
}

\author{
Jacobus Widiatmoko ${ }^{1 *}$ \\ Maria Goreti Kentris Indarti ${ }^{2}$ \\ Chika Adelia Agustin ${ }^{3}$ \\ ${ }^{1,2,3}$ Fakultas Ekonomika dan Bisnis, Universitas Stikubank Semarang \\ *Corresponding author email: jwidiatmoko@edu.unisbank.ac.id
}

\begin{abstract}
The purpose of this study was to examine the effect of institutional ownership, managerial ownership, and growth opportunities on accounting conservatism. This study uses two control variables, namely profitability and leverage. The population in this study were all manufacturing companies listed on the Indonesia Stock Exchange (IDX) in 2017-2019. The sample selection using the purposive sampling technique resulted in 246 data. The test results with ordinary least square regression indicate that institutional ownership has a positive effect on accounting conservatism. Institutional shareholders become an effective supervisory mechanism so that management will act conservatively. On the other hand, managerial ownership shows the opposite result of the hypothesis, and growth opportunities have no effect on accounting conservatism. As predicted, profitability as a control variable has a positive effect on accounting conservatism, but leverage has no effect on accounting conservatism.
\end{abstract}

Keywords: growth opportunities, institutional ownership, managerial ownership, accounting conservatism.

\begin{abstract}
Abstrak
Tujuan penelitian ini adalah menguji pengaruh kepemilikan institusional, kepemilikan manajerial, dan growth opportunities terhadap konservatisme akuntansi. Penelitian ini menggunakan dua variabel kontrol yaitu profitabilitas dan leverage. Populasi dalam penelitian ini adalah seluruh perusahaan manufaktur yang terdaftar di Bursa Efek Indonesia (BEI) tahun 2017-2019. Pemilihan sampel dengan menggunakan teknik purposive samping menghasilkan 246 data. Hasil pengujian dengan regresi ordinary least square menunjukkan bahwa kepemilikan institusional berpengaruh positif terhadap konservatisme akuntansi. Pemegang saham institusi menjadi mekanisme pengawasan yang efektif sehingga manajemen akan bertindak konsrvatif. Sebaliknya, kepemilikan manajerial menunjukkan hasil terbalik dari hipotesis, dan growth opportunities tidak berpengaruh terhadap konservatisme akuntansi. Sesuai yang diprediksi, profitabilitas sebagai variabel control berpengaruh positif terhadap konservatisme akuntansi, namun leverage tidak berpengaruh terhadap konservatisme akuntansi.
\end{abstract}

Kata kunci: growth opportunities, kepemilikan institusional, kepemilikan manajerial, konservatisme akuntansi. 


\section{PENDAHULUAN}

Secara umum laba menjadi pedoman bagi pengguna internal maupun eksternal dalam mengambil berbagai keputusan (De Simone, 2016). Informasi yang berkualitas hanya akan diperoleh dari perusahaan dengan laba yang berkualitas tinggi, karena laba tersebut akan memberikan informasi lebih banyak tentang kinerja keuangan perusahaan yang relevan untuk pengambilan keputusan (Dechow, Ge, dan Schrand, 2010; Widiatmoko dan Indarti, 2019). Kualitas laba dapat dijelaskan melalui relevansi dan keandalan laporan keuangan. Terdapat beberapa indikator kualitas laba, salah satunya adalah konservatisme (Ahmed, 2020).

Konservatisme adalah sebuah konsep penerapan prinsip kehati-hatian dalam pengakuan transaksi yang dipengaruhi oleh ketidakpastian ekonomi dengan cara mengantisipasi jumlah yang lebih kecil untuk nilai aset dan pendapatan, tetapi proyeksi yang lebih besar untuk kewajiban dan biaya. Tujuannya untuk mencegah penyajian pendapatan yang berlebihan dalam pelaporan keuangan dan penyajian biaya dan kerugian yang terlalu rendah (Asiriuwa et al., 2019). Laporan keuangan yang konservatif dapat mencegah adanya asimetri informasi dengan cara membatasi manajemen dalam melakukan manipulasi laporan keuangan (Andreas et al., 2017).

Meskipun konservatisme merupakan indikator kualitas laba suatu perusahaan, namun fenomena menunjukkan bahwa masih terdapat perusahaan di Indonesia yang tidak menerapkan prinsip tersebut. Salah satunya adalah PT Garuda Indonesia. Pada tahun 2019, dua komisaris perusahaan tersebut tidak menyetujui pencatatan laporan keuangan tahun 2018 karena adanya pengakuan lebih cepat terhadap pendapatan. Pengakuan lebih cepat terhadap pendapatan ini menyebabkan perusahaan dapat membukukan laba, yang sebenarnya dalam kondisi rugi. Dampak peristiwa ini dapat menyesatkan pengguna laporan keuangan $(\mathrm{CNN}$, 2019). Kasus manipulasi terhadap laporan keuangan dapat menyebabkan turunnya kepercayaan publik, khusunya pengguna laporan keuangan. Kondisi ini mendorong perusahaan untuk menerapkan prinsip konservatisme akuntansi (Hakiki dan Solikhah, 2019). Konservatisme dapat mengurangi perilaku oportunistik manajer, sehingga dapat meningkatkan kualitas informasi keuangan (Yunos et al., 2014).

Berdasarkan perspektif teori agensi, tindak kecurangan yang dilakukan oleh manajemen merupakan indikasi adanya masalah agensi dalam perusahaan tersebut. Masalah ini dapat diminimalkan melalui mekanisme tata kelola perusahaan yang baik (good corporate governance), yang mengarah pada kepentingan yang selaras. (Indarti et al., 2020). Corporate governance dapat menjadi sarana untuk membangun kerangka kerja yang efisien, adil, transparan dan akuntabel, sehingga dapat menurunkan biaya agensi (Widiatmoko et al., 2020). Implementasi corporate governance yang baik juga dapat digunakan untuk meminimalkan moral hazard dan mendorong manajemen untuk mengelola perusahaan secara efisien serta menyajikan informasi keuangan secara transparan dan tepat waktu. Oleh karena itu, konservatisme akuntansi cenderung dipengaruhi oleh kualitas corporate governance. Struktur kepemilikan yang menggambarkan pengaturan kepemilikan saham dan menentukan kendali terhadap sebuah perusahaan merupakan hal yang fundamental dalam mekanisme corporate governance, yang akan berdampak pula pada konservatisme akuntansi (Krismiaji, 2020).

Kepemilikan institusional merupakan jumlah saham yang dimiliki oleh institusional (eksternal) perusahaan. Berdasarkan perspektif agensi, kepemilikan saham oleh institusi merupakan bentuk mekanisme monitoring untuk meminimalkan konflik agensi. Kepemilikan 
institutional akan mendorong peningkatan pengawasan kepada manajer agar memperoleh kinerja yang optimal (Savitri, 2016). Pengawasan yang ketat antara lain digunakan untuk menghindari manajemen laba yang berlebihan sehingga mendorong diterapkannya konservatisme akuntansi (Hakiki dan Solikhah, 2019). Oleh karena itu, semakin tinggi kepemilikan saham oleh institusi, maka semakin kuat implementasi metode akuntansi yang konservatif. Hasil Penelitian yang dilakukan oleh (El-haq et al., 2019) dan (Putra et al., 2019) menyimpulkan bahwa Kepemilikan institusional berpengaruh positif dan signifikan terhadap penerapan konservatsime akuntansi. Namun, hasil penelitian yang dilakukan oleh Savitri (2016) dan Brilianti (2013) menunjukkan bahwa kepemilikan institusional tidak berpengaruh terhadap praktik konservatisme akuntansi. Asiriuwa et al., (2019) yang melakukan pengujian pengaruh kepemilikan institusional terhadap konservatisme akuntansi di industry perbankan di Nigeria Stock Exchange juga memberikan hasil yang sama.

Kepemilikan manajerial adalah jumlah saham yang dimiliki oleh manajer dari total jumlah saham yang beredar. Keterlibatan manajemen dalam pemilikan saham akan meminimalisir tindakan opportunistik manajemen. Manajemen akan lebih berhati-hati dan berusaha untuk meminimumkan biaya agensi sehingga bisa meningkatkan nilai perusahaan. Kepemilikan saham oleh manajemen akan mendorong manajemen untuk lebih memperhatikan kualitas laba, yang akan berdampak pada nilai saham perusahaan. Oleh karena itu, manajemen akan menerapkan metode akuntansi yang konservatif untuk meningkatkan kualitas laba perusahaan (Hakiki dan Solikhah, 2019). Hasil penelitian yang dilakukan oleh Andreas et al., (2017), Agustina et al., (2016), Septian dan Anna (2014) dan Putra et al., (2019) membuktikan bahwa kepemilikan manajerial berpengaruh positif terhadap penerapan konservatsime akuntansi. Semakin tinggi jumlah saham yang dimiliki akan mendorong manajemen untuk bertindak secara konservatif. Namun, hasil yang berbeda ditemukan oleh El-Haq et al., (2019), Wulandari et al., (2014), Fitriani et al., (2019), dan Asiriuwa et al., (2019) yang menyimpulkan bahwa kepemilikan manajerial tidak berpengaruh terhadap penerapan konservatsime akuntansi.

Growth Opportunities merupakan kesempatan suatu perusahaan untuk bertumbuh. Perusahaan yang memiliki growth opportunities yang tinggi akan cenderung membutuhkan dana yang cukup besar untuk membiayai pertumbuhan tersebut di masa yang akan datang. Perusahaan dengan kesempatan bertumbuh yang tinggi cenderung menerapkan prinsip konservatisme akuntansi dalam pelaporan keuangannya agar direspon positif oleh pasar, sehingga perolehan dana menjadi lebih mudah (Susanti, 2018). Beberapa penelitian telah membuktikan bahwa semakin tinggi jumlah saham dimiliki oleh manajemen, maka semakin tinggi tingkat implementasi konservatisme akuntansi. Penelitian tersebut dilakukan oleh ElHag et al., (2019), Ursula dan Adhivinna (2018), Agustina et al., (2016), Wulandari et al., (2014) yang menyimpulkan bahwa growth opportunities berpengaruh positif terhadap penerapan konservatsime akuntansi. Sebaliknya, hasil penelitian Septian dan Anna (2014), Fitriani et al., (2019) dan Savitri (2016) menunjukkan bahwa growth opportunities tidak berpengaruh terhadap implementasi konservatisme akuntansi.

Hasil penelitian yang tidak konsisten tersebut mendorong dilakukannya pengujian Kembali pengaruh struktur kepemilikan dan growth opportunities terhadap konservatisme akuntansi. Penelitian ini penting dilakukan karena penggunaan rerangka konseptual pelaporan keuangan baru yang tidak memasukkan konservatisme atau prudence sebagai salah satu unsur kualitas, sementara bukti empiris yang dikemukakan di atas menunjukkan bahwa konservatisme merupakan salah satu unsur dan proksi kualitas informasi. Hasil penelitian ini diharapkan memberi kontribusi pada pengembangan literatur akuntansi keuangan dengan 
data terkini pada perusahaan manufaktur yang terdaftar di Bursa Efek Indonesia (BEI). Penelitian ini juga memasukkan dua variabel kontrol, yaitu profitabilitas dan leverage yang pada penelitian sebelumnya telah terbukti berpengaruh terhadap praktik konservatisme akuntansi. Tujuannya adalah untuk memperbaiki model penelitian yang dibangun.

\section{TINJAUAN LITERATUR DAN PERUMUSAN HIPOTESIS}

\section{Teori Agensi}

Teori yang mendasari hubungan antara struktur kepemilikan, growth opportunities dan konservatisme adalah teori agensi. Teori agensi menjelaskan hubungan kontraktual antara pemegang saham atau prinsipal dan manajer sebagai agen (Jensen \& Meckling, 1976). Hubungan agensi ini dapat menimbulkan masalah atau konflik kepentingan, karena agen tidak selalu bertindak sesuai dengan kepentingan prinsipal. Namun, konflik ini dapat diminimalkan dengan mekanisme pemantauan melalui tata kelola perusahaan yang baik, yang mengarah pada kepentingan yang selaras, sehingga dapat menurunkan biaya agensi (Indarti et al., 2020).Tata Kelola Perusahaan adalah seperangkat aturan, prosedur dan administrasi kontrak perusahaan dengan pemegang saham, kreditur, karyawan, pemasok, pelanggan dan pemerintah.

Tata kelola perusahaan yang baik dapat digunakan untuk meminimalkan moral hazard dan mendorong manajemen untuk mengelola perusahaan secara efisien serta menyajikan informasi keuangan secara transparan dan tepat waktu. Salah satu karakteristik kualitatif yang mencakup persyaratan ini adalah konservatisme akuntansi. Konservatisme akuntansi merupakan proses penentuan nilai agar asset dan penghasilan tidak dilaporkan terlalu tinggi dan liabilitas dan beban tidak dilaporkan terlalu rendah (IASB, 2018). Konservatisme akuntansi merupakan fitur penting dalam mengukur kualitas pelaporan keuangan. Oleh karena itu, konservatisme akuntansi cenderung dipengaruhi oleh kualitas corporate governance.

Struktur kepemilikan yang menggambarkan pengaturan kepemilikan saham dan menentukan kendali terhadap sebuah perusahaan merupakan hal yang fundamental dalam mekanisme corporate governance. Proporsi kepemilikan saham pada perusahaan public akan mempengaruhi pelaporan keuangan oleh manajemen, sehingga akan berdampak pula pada konservatisme akuntansi (Krismiaji, 2020).

\section{Kepemilikan Institusional dan Konservatisme Akuntansi}

Kepemilikan institusional menunjukkan jumlah saham biasa yang dimiliki oleh pihak institusional (Indarti et al., 2020). Berdasarkan perspektif agensi, kepemilikan saham oleh institusi merupakan bentuk mekanisme monitoring untuk meminimalkan konflik agensi. Pemegang saham institusional termotivasi untuk mengelola perusahaan secara efisien, karena mereka memiliki investasi dan wewenang yang besar untuk membuat keputusan dalam meningkatkan kinerja keuangan perusahaan (Jensen dan Meckling, 1976). Investor institusional lebih terfokus pada laba masa datang (future earnings) yang relatif lebih besar dari laba sekarang. Investor institusional tergolong kedalam investor yang berpengalaman (sophisticated) sehingga mereka akan melakukan monitoring secara efektif dan cenderung skeptis terhadap tindakan dari pihak manajemen (Putra et al., 2019). Oleh karena itu mereka akan melakukan pengawasan terhadap kinerja manajemen. Pengawasan yang ketat antara lain 
digunakan untuk menghindari manajemen laba yang berlebihan sehingga mendorong diterapkannya konservatisme akuntansi (Hakiki dan Solikhah, 2019). Semakin tinggi jumlah saham yang dimiliki institusi, maka semakin tinggi tingkat konservatisme akuntansi diimplementasi oleh manajemen.

Logika pemikiran tersebut didukung oleh penelitian El-Haq et al., (2019), Hakiki dan Soliha (2019) dan Putra et al., (2019) yang membuktikan bahwa semakin tinggi jumlah saham yang dimiliki oleh institusi, semakin tingkat konservatisme akuntansi. Hasil yang sama juga ditunjukkan oleh Al Kurdi et al., (2017) yang meneliti pengaruh kepemilikan institusional terhadap konservatisme akuntansi di Jordania. Oleh karena itu diajukan hipotesis berikut ini.

\section{$\mathrm{H}_{1}$ : Kepemilikan institusional berpengaruh positif terhadap penerapan konservatisme akuntansi}

\section{Kepemilikan Manajerial dan Konservatisme Akuntansi}

Berdasarkan perspektif teori agensi, kepemilikan saham oleh manajemen dapat dijadikan sebagai sarana untuk mengurangi konflik antara manajemen dengan pemegang saham. Kepemilikan manajerial adalah jumlah saham yang dimiliki oleh manajer dari total jumlah saham yang beredar (Widhiastuti et al., 2019). Ketika manajer juga merupakan pemegang saham, maka mereka akan menjalankan tugasnya untuk kepentingan terbaik perusahaan. Selain itu, mereka cenderung lebih berhati-hati dalam menjalankan operasi, yang mengarah pada manajemen yang efisien (Indarti et al., 2020). Oleh karena itu, jika kepemilikan saham oleh manajer lebih dari investor lain, maka manajemen cenderung melaporkan laba secara lebih konservatif.

Penelitian yang dilakukan oleh Putra et al., (2019) dan El-Haq et al., (2019) membuktikan bahwa kepemilikan manajerial berpengaruh positif terhadap konservatisme akuntansi. Semakin tinggi jumlah saham yang dimiliki oleh manajemen, semakin tinggi tingkat konservatisme akuntansi yang diterapkan oleh manajemen. Hasil penelitian tersebut sejalan dengan temuan penelitian yang dilakukan oleh Septian dan Anna, (2014). Berdasarkan logika dan dukungan empiris tersebut, hipotesis dirumuskan sebagai berikut.

\section{H2: Kepemilikan manajerial berpengaruh positif terhadap penerapan konservatisme akuntansi.}

\section{Growth Opportunities dan Konservatisme Akuntansi}

Growth opportunities adalah kesempatan perusahaan untuk melakukan investasi pada hal-hal yang menguntungkan (Agustina et al., (2016). Perusahaan yang memiliki growth opportunities tinggi membutuhkan dana untuk membiayai pertumbuhannya. Perusahaan dengan kesempatan bertumbuh yang tinggi cenderung menerapkan prinsip konservatisme akuntansi dalam pelaporan keuangannya agar direspon positif oleh pasar, sehingga perolehan dana menjadi lebih mudah (Susanti, 2018). Respon positif terjadi karena perusahaan yang memiliki kesempatan investasi mengalami kenaikan arus kas masa depan (Savitri, 2016).

Beberapa penelitian telah membuktikan bahwa perusahaan dengan growth opportunities yang semakin tinggi cenderung menerapkan konservatisme akuntansi. El-Haq et al., (2019), Ursula dan Adhivinna (2018), Agustina et al., (2016), dan Wulandari et al., (2014) membuktikan bahwa growth opportunities berpengaruh positif terhadap konservatisme 
akuntansi. Semakin tinggi kesempatan bertumbuh yang dimiliki oleh suatu perusahaan, manajemen termotivasi untuk menerapkan prinsip koservatisme akuntansi. Berdasarkan logika pemikiran dan dukungan penelitian sebelumnya, hipotesis dirumuskan sebagai berikut.

\section{H3: Growth opportunities berpengaruh positif terhadap penerapan konservatisme akuntansi.}

\section{METODE PENELITIAN}

\section{Populasi dan Sampel Penelitian}

Populasi dalam penelitian ini adalah perusahaan manufaktur yang terdaftar di Bursa Efek Indonesia selama tahun 2017 sampai dengan 2019. Teknik pengambilan sampel menggunakan purposive sampling, yaitu teknik pengambilan sampel dengan menggunakan kriteria tertentu. Kriteria tersebut adalah perusahaan manufaktur yang menerbitkan laporan keuangan dan memiliki data lengkap. Berdasarkan kriteria tersebut, diperoleh data sebanyak 246 observasi perusahaan.

\section{Definisi Operasional dan Pengukuran Variabel}

Penelitian ini menggunakan konservatisme akuntansi sebagai variabel dependen dan kepemilikan institusional, manajerial dan growth opportunity sebagai variable dependen. Sementara itu, leverage dan profitabilitas digunakan sebagai variable kontrol. Definisi operasional dan pengukuran masing-masing variabel disajikan pada Tabel 1.

Tabel 1. Definisi dan Pengukuran Variabel

\begin{tabular}{|c|c|c|}
\hline Variabel & Definisi Operasional & Pengukuran \\
\hline $\begin{array}{l}\text { Konservatisme } \\
\text { akuntansi }\end{array}$ & $\begin{array}{l}\text { Prinsip yang mengakui biaya dan rugi lebih } \\
\text { cepat, mengakui pendapatan dan untung } \\
\text { lebih lambat, menilai aset dengan nilai yang } \\
\text { terendah dan kewajiban dengan nilai yang } \\
\text { tinggi. }\end{array}$ & 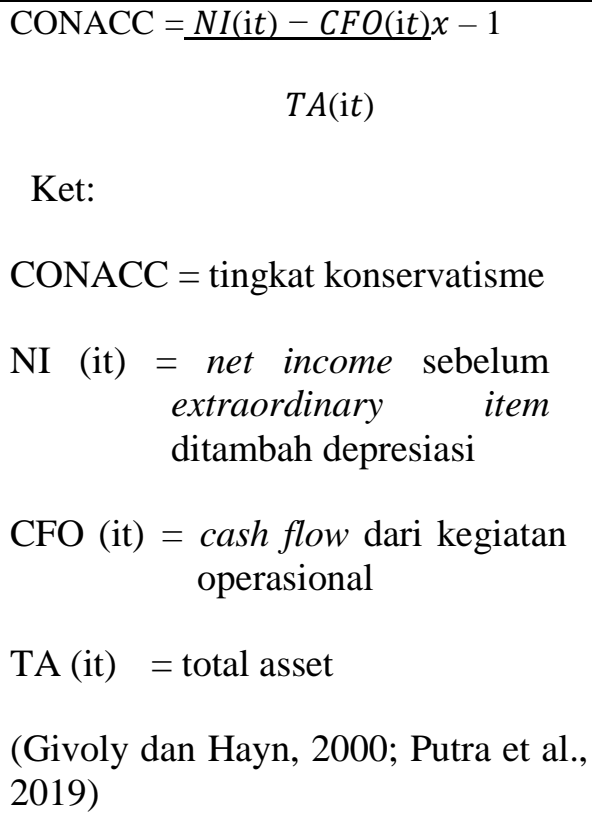 \\
\hline $\begin{array}{l}\text { Kepemilikan } \\
\text { Institusional }\end{array}$ & $\begin{array}{l}\text { Persentase jumlah saham yang dimiliki } \\
\text { institusi terhadap jumlah saham yang }\end{array}$ & $\mathrm{IO}=\underline{\mathrm{Jml} \text { saham yg dimiliki institusi }}$ \\
\hline
\end{tabular}


Jurnal Akuntansi Bisnis, Vol. 18, No. 2, September 2020

ISSN 1412-775X (media cetak) | 2541-5204 (media online)

\begin{tabular}{|c|c|c|}
\hline (IO) & beredar. & $\begin{array}{l}\text { Jml saham yang beredar } \\
\text { (El-haq et al., 2019) }\end{array}$ \\
\hline $\begin{array}{c}\text { Kepemilikan } \\
\text { Manajerial } \\
\text { (MO) }\end{array}$ & $\begin{array}{l}\text { Persentase jumlah saham yang dimiliki } \\
\text { manajer terhadap jumlah saham yang } \\
\text { beredar. }\end{array}$ & 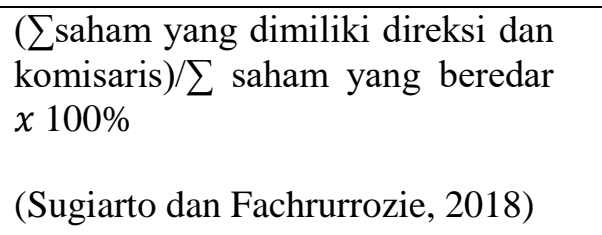 \\
\hline $\begin{array}{l}\text { Growth } \\
\text { Opportunity } \\
\text { (GO) }\end{array}$ & $\begin{array}{l}\text { Growth Opportunity merupakan } \\
\text { kesempatan perusahaan untuk tumbuh. } \\
\text { diproksikan dari market to book value } \\
\text { equity. }\end{array}$ & $\begin{array}{l}\mathrm{GO}=(\text { Saham yang beredar } \mathrm{x} \text { harga } \\
\text { penutupan saham)/Total ekuitas } \\
(\text { El-haq et al., 2019) }\end{array}$ \\
\hline $\begin{array}{c}\text { Profitabilitas } \\
\text { (ROA) }\end{array}$ & $\begin{array}{l}\text { Profitabilitas } \text { adalah } \quad \text { kemampuan } \\
\text { perusahaan untuk memperoleh laba atau } \\
\text { keuntungan }\end{array}$ & $\begin{array}{l}\mathrm{ROA}=\underline{\text { Laba Bersih }} \times \frac{100 \%}{\text { Total Aset }} \\
\text { (Widiatmoko \& Indarti, 2018) }\end{array}$ \\
\hline $\begin{array}{c}\text { Leverage } \\
\text { (DAR) }\end{array}$ & $\begin{array}{l}\text { Kemampuan perusahaan untuk membayar } \\
\text { seluruh hutangnya }\end{array}$ & $\begin{array}{l}\text { DAR }=\text { Total hutang } \\
\qquad \text { Total Aset } \\
\text { (Indarti dan Widiatmoko, 2021; } \\
\text { Widiatmoko dan Indarti, 2018) }\end{array}$ \\
\hline
\end{tabular}

Sumber: dirangkum dari berbagai sumber

\section{Teknik dan Analisis}

Teknik analisis yang digunakan dalam penelitian ini adalah regresi ordinary least square (OLS), dengan menggunakan persamaan berikut ini.

$$
\mathrm{CONNACC}=\alpha+\beta 1 \mathrm{IO}+\beta 2 \mathrm{MO}+\beta 3 \mathrm{GO}+\beta 4 \mathrm{ROA}+\beta 5 \mathrm{DAR}+\mathrm{e}
$$

Dimana:

$$
\begin{array}{ll}
\text { CONNACC } & =\text { Konservatisme Akuntansi } \\
\alpha & =\text { Konstanta } \\
\beta & =\text { Koefisien Beta } \\
\text { IO } & =\text { Kepemilikan institusional } \\
\text { MO } & =\text { Kepemilikan manajerial } \\
\text { GO } & =\text { Growth Opportunities } \\
\text { ROA } & =\text { Profitabilitas }
\end{array}
$$




$$
\begin{array}{ll}
\text { DAR } & =\text { Leverage } \\
e & =\text { error }
\end{array}
$$

Sebagai syarat penggunaan regresi OLS, sebelumnya dilakukan penggujian normalitas dan asumsi klasik, yang meliputi uji multikolinearitas, autokorelasi, dan heteroskedastisitas.

\section{HASIL DAN PEMBAHASAN}

\section{Statistik Deskriptif}

Statistik deskriptif menggambarkan karakteristik variable berdasarkan nilai rata-rata (mean), nilai minimum, maksimun, dan deviasi standar. Tabel 2 menyajikan statistik deskriptif seluruh variabel yang digunakan dalam penelitian ini.

Tabel 2. Statistik Deskriptif

\begin{tabular}{|c|r|r|r|r|r|}
\hline Variabel & $\mathbf{N}$ & Minimum & Maksimum & Rata-rata & $\begin{array}{c}\text { Deviasi } \\
\text { standar }\end{array}$ \\
\hline $\begin{array}{c}\text { Konservatisme } \\
\text { Akuntansi }\end{array}$ & 226 & $-0,1868$ & 0,1622 & 0,013700 & 0,0560649 \\
\hline $\begin{array}{c}\text { Kepemilikan } \\
\text { Manjaerial }\end{array}$ & 226 & 0,0000 & 0,7320 & 0,104423 & 0,1732853 \\
\hline $\begin{array}{c}\text { Kepemilikan } \\
\text { Institusional }\end{array}$ & 226 & 0,0002 & 0,9329 & 0,460390 & 0,2832829 \\
\hline $\begin{array}{c}\text { Growth } \\
\text { Opportunities }\end{array}$ & 226 & $-18,4872$ & 100,6930 & 3,754815 & 11,3444401 \\
\hline Profitabilitas & 226 & $-0,2099$ & 0,4666 & 0,039793 & 0,0774833 \\
\hline Leverage & 226 & 0,0758 & 5,0733 & 0,521236 & 0,5531160 \\
\hline
\end{tabular}

Sumber: data sekunder diolah

Variabel konservatisme akuntansi memiliki nilai minimum sebesar -0,1868, nilai maksimum 0,1622, dan nilai rata-rata 0,013700. Kondisi ini menunjukkan bahwa perusahaan sampel memiliki tingkat konservatisme yang rendah. Kepemilikan manajerial menunjukkan nilai minimum sebesar 0.00000 , nilai maksimum 0,7320 dan nilai rata-rata sebesar 0,104423 . Kepemilikan saham oleh manajemen pada perusahaan manufaktur relatif rendah, yaitu sekitar 10,44\%. Kepemilikan Institusional menunjukkan nilai minimum sebesar 0.0002, nilai maksimum 0,9329 dan nilai rata-rata sebesar 0,460390. Kepemilikan saham oleh institusi pada perusahaan manufaktur relatif sedang, yaitu sekitar 46,04\%. Nilai minimum pada variabel growth opportunities sebesar -18,4872, nilai maksimum sebesar 100,6930, dan nilai rata-rata sebesar 3,754815. Hasil ini dapat dimaknai bahwa rata-rata sampel penelitian memiliki kesemptan bertumbuh yang baik. 
Statistik deskriptif untuk profitabilitas menunjukkan nilai minimum sebesar -0,2099, nilai maksimum sebesar 0,4666, dan nilai rata-rata sebesar 0,039793. Hasil ini menunjukkan bahwa kemampuan menghasilkan laba dari perusahaan sampel rata-rata rendah, hanya sebesar 3,98\%. Variabel leverage, memiliki nilai minimum sebesar 0,0758, nilai maksimum sebesar 5,0733, dan nilai rata-rata sebesar 0,521236. Hasil tersebut menunjukkan bahwa perusahaan sampel menghadapi kewajiban keuangan sedang, 52,12\%. Berdasarkan perbandingan antara nilai rata-rata dan standar deviasi dapat diketahui bahwa lima variabel, yaitu konservatisme akuntansi, kepemilikan manajerial, growth opportunities, profitabilitas dan leverage, memiliki nilai standar deviasi yang lebih tinggi daripada nilai rata-rata. Hal ini dapat diartikan bahwa sebaran data untuk kelima variabel pada perusahaan sampel berfluktuasi. Sementara itu, variabel kepemilikan institusional memiliki nilai rata-rata (mean) lebih besar dari standar deviasi, yang berarti sebaran data tidak berfluktuasi.

\section{Hasil Pengujian}

Ringkasan hasil pengujian normalitas residual, asumsi klasik dan regresi linear berganda disajikan pada Tabel 3. Sebagai syarat penggunaan regresi ordinary least square (OLS), sebelumnya dilakukan pengujian normalitas residual dan asumsi klasik. Hasil pengujian normalitas dengan skewness seperti terlihat di Tabel 3 menunjukkan angka 0,096. Hasil pengujian multikolinearitas menunjukkan bahwa seluruh variabel independen memiliki nilai tolerance di atas 1 dan nilai variance inflation factor (VIF) kurang dari 10. Nilai run test menunjukkan angka 0,00283 dengan tingkat signifikansi 0,142. Sementara itu, hasil pengujian heteroskedastisitas menunjukkan nilai signifikansi di atas 0,05. Dapat disimpulkan bahwa dalam model regresi kesalahan residu terdistribusi normal dan memenuhi asumsi klasik.

\section{Tabel 3. Hasil Pengujian Regresi}

\begin{tabular}{|c|c|c|c|c|c|c|c|c|}
\hline \multirow{2}{*}{ Model } & \multicolumn{2}{|c|}{$\begin{array}{c}\text { Unstandardized } \\
\text { Coefficients }\end{array}$} & \multirow{2}{*}{$\mathrm{t}$} & \multirow{2}{*}{ Sig. } & \multicolumn{2}{c|}{$\begin{array}{c}\text { Collinearity } \\
\text { Statistics }\end{array}$} & \multicolumn{2}{c|}{$\begin{array}{c}\text { Heteroscedasticity } \\
\text { test }\end{array}$} \\
\cline { 2 - 8 } & $\beta$ & Std. Error & & & Tolerance & VIF & $\mathrm{t}$ & Sig. \\
\hline (Constant) & $-0,005$ & 0,009 & $-0,491$ & 0,624 & & & & \\
\hline IO & 0,033 &, 013 & $-2,495$ & 0,011 & 0,862 & 1,161 & $-0,047$ & 0,485 \\
\hline MO & $-0,052$ & 0,021 & 2,552 & 0,013 & 0,881 & 1,135 & 0,021 & 0,757 \\
\hline GO & 0,000 & 0,000 & $-0,434$ & 0,665 & 0,949 & 1,054 & $-0,039$ & 0,557 \\
\hline Profitabilitas & 0,265 & 0,006 & 5,846 & 0,000 & 0,924 & 1,082 & 0,065 & 0,330 \\
\hline Leverage & $-0,003$ & 0,045 & $-0,423$ & 0,673 & 0,926 & 1,080 & 0,019 & 0,775 \\
\hline Z skewness & & & & & & & & \\
\hline Run test value & & & & & & & & \\
\hline Sig. & & & & & & & & \\
\hline
\end{tabular}




\begin{tabular}{|c|l|l|l|l|l|l|l|c|}
\hline $\begin{array}{c}\text { Adjusted R } \\
\text { Square }\end{array}$ & & & & & & & & 0,187 \\
\hline F Statistics: & & & & & & & & 11,325 \\
\hline Sig. & & & & & & & & 0,000 \\
\hline
\end{tabular}

Sumber: data sekunder diolah

Nilai adjusted $R$ square pada Tabel 3 menunjukkan angka sebesar 0,187, yang berarti bahwa $18,70 \%$ variasi dalam konservatisme akuntansi dapat dijelaskan oleh kepemilikan institusional, kepemilikan manajerial, growth opportunities, profitabilitas, dan leverage, sedangkan sisanya sebesar $80,30 \%$ dijelaskan oleh variabel lain yang tidak masuk dalam model. Nilai $F$ statistics menunjukkan angka 11,325 dengan nilai signifikansi 0,000 , yang berarti bahwa secara bersama-sama variabel kepemilikan institusional, kepemilikan manajerial, growth opportunities, profitabilitas dan leverage berpengaruh terhadap konservatisme akuntansi.

Hasil pengujian hipotesis kepemilikan institusional menunjukkan nilai koefisen beta sebesar 0,033 dengan tingkat signifikansi sebesar 0,011. Oleh karena itu, hipotesis pertama yang menyatakan kepemilikan institusional berpengaruh positif terhadap konservatisme akuntansi diterima. Variabel kepemilikan manajerial memiliki koefisien beta sebesar $-0,052$ dengan nilai signifikansi 0,013 , sehingga hipotesis kedua yang menyatakan bahwa kepemilikan manajerial berpengaruh positif terhadap konservatisme akuntansi ditolak. Nilai koefisien beta pada variabel growth opportunities menunjukkan angka 0,000 dengan nilai signifikansi 0,665, sehingga hipotesis ketiga yang menyatakan bahwa growth opportunity berpengaruh positif terhadap konservatisme akuntansi ditolak. Sesuai dengan yang diprediksi, profitabilitas berpengaruh positif terhadap konservatisme akuntansi. Sebaliknya, leverage tidak berpengaruh terhadap konservatisme akuntansi.

\section{Pembahasan}

Hasil pengujian hipotesis pertama menunjukkan bahwa kepemilikan institusional berpengaruh positif terhadap praktik konservatisme akuntansi. Berdasarkan hasil tersebut maka hipotesis pertama diterima. Temuan ini mendukung teori agensi bahwa kepemilikan saham oleh institusi merupakan wujud corporate governance sebagai mekanisme pengawasan kepada pihak manajemen. Investor institusional lebih terfokus pada laba masa datang (future earnings) yang relatif lebih besar dari laba sekarang. Investor institusional tergolong kedalam investor yang berpengalaman (sophisticated) sehingga mereka akan melakukan monitoring secara efektif dan cenderung skeptis terhadap tindakan dari pihak manajemen (Putra et al., 2019). Oleh akrena itu mereka akan melakukan pengawasan terhadap kinerja manajemen. Pengawasan yang ketat antara lain digunakan untuk menghindari manajemen laba yang berlebihan sehingga mendorong diterapkannya konservatisme akuntansi (Hakiki dan Solikhah, 2019). Hasil penelitian ini mendukung temuan penelitian El-Haq et al., (2019), Hakiki dan Soliha (2019), Putra et al., (2019) dan Al Kurdi et al., (2017) yang membuktikan bahwa semakin tinggi jumlah saham yang dimiliki oleh institusi, semakin tinggi tingkat konservatisme akuntansi diimplementasi.

Hasil pengujian hipotesis kedua menunjukkan bahwa kepemilikan manajerial memiliki pengaruh negatif signifikan terhadap konservatisme akuntansi. Semakin tinggi jumlah saham yang dimiliki oleh manajemen, maka manajemen akan semakin tidak konservatif. 
Berdasarkan hasil ini maka hipotesis kedua ditolak. Hasil ini tidak sejalan dengan teori agensi yang menyatakan bahwa kepemilikan saham oleh manajemen dapat digunakan sebagai mekanisme penyelarasan kepentingan dengan pemegang saham. Penjelasan yang dapat diberikan adalah kepemilikan saham oleh manajemen pada perusahaan sampel relatif rendah, yaitu 10,44\%, sehingga manajemen cenderung bertindak oportunistik. Selain itu, manajemen cenderung termotivasi untuk mencatatkan laba yang besar, sehingga akan direspon positif oleh pasar. Perusahaan dengan laba besar akan lebih mudah untuk mendapatkan sumber pendanaan dari kreditur maupun calon investor. Hasil penelitian ini tidak konsisten dengan temuan penelitian sebelumnya yang dilakukan oleh Putra et al., (2019), El-Haq et al., (2019), Putra dan Subowo, (2016) dan Septian \& Anna (2014), yang membuktikan bahwa kepemilikan manajerial berpengaruh positif terhadap konservatisme akuntansi.

Hipotesis ketiga yang menyatakan bahwa growth opportunities berpengaruh negatif terhadap konservatisme akuntansi ditolak. Perusahaan yang menjadi sampel dalam penelitian ini memiliki rata-rata kesempatan bertumbuh yang relatif rendah, yaitu 3,7548. Nilai kesempatan bertumbuh yang rendah ini menunjukkan bahwa perusahaan tidak konservatif, karena perusahaan yang menerapkan prinsip konservatisme akuntansi memiliki cadangan yang tersembunyi yang dapat digunakan untuk investasi. Oleh karena itu, perusahaan yang konservatif identik dengan perusahaan yang memiliki kesempatan bertumbuh tinggi. Hasil penelitian ini tidak mendukung temuan penelitian sebelumnya yang dilakukan oleh El-Haq et al., (2019), Agustina et al., (2016), dan Wulandari et al., (2014) yang membuktikan bawa semakin tinggi kesempatan bertumbuh yang dimiliki oleh perusahaan, semakin tinggi tingkat konservatisme akuntansi yang diimplementasikan.

\section{SIMPULAN DAN SARAN}

\section{Simpulan}

Penelitian ini menguji pengaruh kepemilikan institusional, manajerial dan growth opportunities terhadap praktik konservatisme akuntansi pada perusahaan manufaktur yang terdaftar di Bursa Efek Indonesia (BEI) tahun 2017-2019. Hasil penelitian menunjukkan bahwa kepemilikan institusional berpengaruh positif terhadap konservatisme akuntansi. Semakin tinggi jumlah saham dimiliki oleh investor institusi, maka semakin ketat pengawasan yang dilakukan terhadap manajemen, sehingga manajemen akan bertindak lebih konservatif. Namun kepemilikan manajerial dan growth opportunity tidak berpengaruh terhadap konservatisme akuntansi. Kepemilikan saham oleh manajemen dalam penelitian ini menunjukkan jumlah yang relatif kecil, sehingga tidak mampu menjadi mekanisme untuk menyelaraskan kepentingan dengan pemegang saham. Sesuai dengan yang diprediksi, profitabilitas berpengaruh positif terhadap konservatisme akuntansi. Sebaliknya, leverage tidak berpengaruh terhadap konservatisme akuntansi.

Penelitian ini memberikan implikasi, baik secara teoritis maupun praktis. Secara teoritis, hasil penelitian ini memberikan bukti bahwa institusi sebagai pemegang saham sebuah perusahaan dapat menjadi mekanisme pengawasan yang efektif terhadap manajemen. Sebaliknya, kepemilikan saham oleh manajemen tidak mampu menyelaraskan kepentingan antara manajemen sebagai agen dengan pemegang saham. Secara praktis, hasil penelitian ini dapat digunakan sebagai bahan pertimbangan bagi calon investor maupun calon kreditor dalam membuat keputusan bisnis mereka. Selain itu, hasil penelitian ini juga dapat menjadi masukan bagi Ikatan Akuntan Indonesia selaku pembuat kebijakan terkait standar akuntansi 
keuangan untuk mempertimbangkan konsep konservatisme dalam rerangka konseptual pelaporan keuangan. Terlepas dari kontribusi yang dapat diberikan, penelitian ini memiliki beberapa keterbatasan yang memerlukan perbaikan pada penelitian di masa yang akan datang. Kemampuan variabel independen dalam menjelaskan variasi variabel dependen relatif rendah, yaitu $18,70 \%$. Selain itu, temuan dalam penelitian ini hanya satu variabel yang berhasil mendukung hipotesis.

\section{Saran}

Saran untuk penelitian yang akan datang agar mempertimbangkan variabel-variabel yang secara teoritis dan empiris mempengaruhi praktik konservatisme akuntansi. Variabel tersebut antara lain komite audit, komisaris independen, kepemilikan saham oleh pemerintah maupun asing dan kualitas audit sebagai mekanisme corporate governance. Selain itu, agar diperoleh hasil yang lebih baik, peneliti selanjutnya dapat memperpanjang periode amatan atau melakukan perbandingan praktik konservatisme akuntansi antar sektor industri.

\section{DAFTAR PUSTAKA}

Agustina, A., Rice, R., \& Stephen, S. 2016. Akuntansi Konservatisme Pada Perusahaan Manufaktur yang Terdaftar di Bursa Efek Indonesia. Jurnal Dinamika Akuntansi Dan Bisnis, 3(1), 1-16. https://doi.org/10.24815/jdab.v3i1.4392

Ahmed, I. E. 2020. The qualitative characteristics of accounting information, earnings quality, and islamic banking performance: evidence from the gulf banking sector. International Journal of Financial Studies, 8(30), 1-16. https://doi.org/10.3390/ijfs8020030

Alkurdi, A., Al-Nimer, M., \& Dabaghia, M. 2017. Accounting conservatism and ownership structure effect: A look at industrial and financial jordanian listed companies. Journal of Environmental Accounting and Management, 7(2), 608-619. https://doi.org/10.5890/JEAM.2017.06.007

Andreas, H. H., Ardeni, A., \& Nugroho, P. I. 2017. Konservatisme Akuntansi di Indonesia. Jurnal Ekonomi Dan Bisnis, 20(1), 1. https://doi.org/10.24914/jeb.v20i1.457

Asiriuwa, O., Akperi, R. T., Uwuigbe, O. R., Uwuigbe, U., Nassar, L., Ilogho, S., \& Eriabe, S. 2019. Ownerships Structures and Accounting Conservatism among Nigeria Listed Firms. IOP Conference Series: Earth and Environmental Science, 331(1), 1-15. https://doi.org/10.1088/1755-1315/331/1/012056

Brilianti, D. P. 2013. Faktor-Faktor Yang Mempengaruhi Penerapan Konservatisme Akuntansi Perusahaan. Accounting Analysis Journal, 2(3), 268-275. https://doi.org/10.15294/aaj.v2i3.2500

CNN, I. 2019. Dua Komisaris Garuda Indonesia Tolak Laporan Keuangan. https://doi.org/https://www.cnnindonesia.com/ekonomi/20190424155941-92-

389264/dua-komisaris-garuda-indonesia-tolak-laporan-keuangan.

De Simone, L. 2016. Does a common set of accounting standards affect tax-motivated income shifting for multinational firms? Journal of Accounting and Economics, 61(1), 
145-165. https://doi.org/10.1016/j.jacceco.2015.06.002

Dechow, P., Ge, W., \& Schrand, C. 2010. Understanding earnings quality: A review of the proxies, their determinants and their consequences. Journal of Accounting and Economics, 50(2-3), 344-401. https://doi.org/10.1016/j.jacceco.2010.09.001

El-haq, Z. N. S., Zulpahmi, Z., \& Sumardi, S. 2019. Pengaruh Kepemilikan Manajerial, Kepemilikan Institusional, Growth Opportunities, Dan Profitabilitas Terhadap Konservatisme Akuntansi. Jurnal ASET (Akuntansi Riset), 11(2), 315-328. https://doi.org/10.17509/jaset.v11i2.19940

Fitriani, E., Maslichah, M., \& Junaidi, J. 2019. Pengaruh Kepemilikan Manajerial, Growth Opportunity, dan Leverage terhadap Konservatisme Akuntansi, 08(07), 14-26. Retrieved from http://riset.unisma.ac.id/index.php/jra/article/view/4227/3773

Givoly, D., \& Hayn, C. 2000. The Changing Time-Series Properties of Earnings, Cash Flows and Accruals. Journal of Accounting and Economics, 29, 287-320. https://doi.org/10.1016/S0165-4101(00)00024-0

Hakiki, L. N., \& Solikhah, B. 2019. Pengaruh Corporate Governance, Investment Opportunity Set, Ukuran Perusahaan, Dan Penerapan Psak 55 Terhadap Konservatisme Akuntansi. Gorontalo Accounting Journal, 2(2), 85-97. https://doi.org/10.32662/gaj.v2i2.620

Indarti, M. G. K., \& Widiatmoko, J. 2021. The Effects of Earnings Management and Audit Quality on Cost of Equity Capital: Empirical Evidence from Indonesia. Journal of Asian Finance, Economics and Business, 8(4), 769-776. https://doi.org/10.13106/jafeb.2021.vol8.no4.0769

Indarti, M. G. K., Widiatmoko, J., \& Pamungkas, I. D. 2020. Corporate Governance Structures and Probability of Financial Distress: Evidence From Indonesia Manufacturing Companies. International Journal of Financial Research, 12(1), 174183. https://doi.org/10.5430/ijfr.v12n1p174

Jensen, M. C., \& Meckling, W. H. 1976. Theory of The Firm: Managerial Behavior, Agency Cost and Ownership Structure. Journal of Financial Economics, 3, 305-360. https://doi.org/10.1016/0304-405X(76)90026-X

Krismiaji, K. 2020. Struktur Kepemilikan Dan Konservatisme Akuntansi. JIAFE (Jurnal Ilmiah Akuntansi Fakultas Ekonomi), 6(2), 149-160. https://doi.org/10.34204/jiafe.v6i2.2358

Putra, I. G. B. N. P., Sari, P. A. M. P., \& Larasdiputra, G. D. 2019. Pengaruh Kepemilikan Institusional Dan Kepemilikan Manajerial Pada Konservatisme Akuntansi. Wacana Ekonomi (Jurnal Ekonomi, Bisnis Dan Akuntansi), Vol.18(No.1), 41-51. https://doi.org/10.22225/we.18.1.991.41-51

Putra, N. Y., \& Subowo, S. 2016. The Effect of Accounting Conservatism, Investment Opportunity Set, Leverage, and Company Size on Earnings Quality. Accounting Analysis Journal, 5(4), 299-306. https://doi.org/10.15294/aaj.v5i4.10691

Savitri, E. 2016. Pengaruh Struktur Kepemilikan Institusional, Debt Covenant Dan Growth 
Opportunities Terhadap Konservatisme Akuntansi. Jurnal Al-Iqtishad, 12(1), 39-54. https://doi.org/10.24014/jiq.v12i1.4444

Septian, A., \& Anna, Y. D. 2014. Pengaruh Kepemilikan Manajerial, Ukuran Perusahaan, Debt Covenant, dan Growth Opportunities Terhadap Konservatisme Akuntansi. In EProceeding of Management (Vol. 1, pp. 352-469).

Sugiarto, V. H. S., \& Fachrurrozie, F. 2018. The Determinant of Accounting Conservatism on Manufacturing Companies in Indonesia. Accounting Analysis Journal, 7(1), 1-9. https://doi.org/10.15294/aaj.v7i1.20433

Susanti, C. M. 2018. Pengaruh Konservatisme, Leverage, Profitabilitas, Ukuran Perusahaan Terhadap Tax Avoidance. Jurnal Informasi, Perpajakan, Akuntansi, Dan Keuangan Publik, 13(2), 181-198. https://doi.org/10.25105/jipak.v13i2.5021

Ursula, E. A., \& Adhivinna, V. V. 2018. Pengaruh Kepemilikan Manajerial, Ukuran Perusahaan, Leverage, Dan Growth opportunities Terhadap Konservatisme Akuntansi. Jurnal Akuntansi, 6(2), 194-206. https://doi.org/10.24964/ja.v6i2.643

Widhiastuti, R., Nurkhin, A., \& Susilowati, N. 2019. The Role of Financial Performance in Mediating The Effect of Good Corporate Governance on Financial Distress. Jurnal Economia, 15(1), 34-47. https://doi.org/10.21831/economia.v15i1.22927

Widiatmoko, J., \& Indarti, M. G. K. 2018. Karateristik Perusahaan, Tipe Auditor dan Konsentrasi Kepemilikan Saham terhadap Pengungkapan Modal Intelektual. Jurnal Bisnis Dan Ekonomi, 25(1), 35-46. Retrieved from https://unisbank.ac.id/ojs/index.php/fe3/article/view/6964

Widiatmoko, J., \& Indarti, M. G. K. (2019). Book Tax Differences, Operating Cash Flow, Leverage and Earning Persistence in Indonesia Manufacturing Companies. Jurnal Dinamika Akuntansi, 11(2), 151-159. https://doi.org/10.15294/jda.v11i2.20481

Widiatmoko, J., Indarti, M. G. K., \& Pamungkas, I. D. (2020). Corporate governance on intellectual capital disclosure and market capitalization. Cogent Business and Management, 7(1), 0-14. https://doi.org/10.1080/23311975.2020.1750332

Wulandari, I., Andreas, A., \& Ilham, E. (2014). Pengaruh Struktur Kepemilikan Manajerial, Debt Covenant dan Growth Opportunity terhadap Konservatisme Akuntansi. JOM Fekom, 1(2), 1-15. Retrieved from http://riset.unisma.ac.id/index.php/jra/article/view/4227/3773

Yunos, R. M., Ahmad, S. A., \& Sulaiman, N. (2014). The Influence of Internal Governance Mechanisms on Accounting Conservatism. Procedia - Social and Behavioral Sciences, 164(March 2017), 501-507. https://doi.org/10.1016/j.sbspro.2014.11.138 